\title{
A magyar jövevényszavak beilleszkedése a muravidéki szlovén irodalmi nyelv rendszerébe
}

1. Magyar-szlovén nyelvi kapcsolatok. A magyar-szlovén nyelvi kapcsolatok intenzitása ugyan nem mérhető ahhoz a magyar nyelvi hatáshoz, amely például a horvát nyelvet érte, ám számos jövevényszó honosodott meg a magyar nyelvterülettel leginkább érintkező muravidéki szlovén nyelvben, amely a 18. század második felére irodalmi nyelvi rangra emelkedett.

A magyar-szlovén nyelvi kapcsolatok színtere tehát a történelmi Vas és Zala vármegye területén elhelyezkedő Muravidék volt, amely ma Szlovénia keleti részén található. A magyar állam- és egyházigazgatás kötelékébe 1090 k. került ez a Muráig terjedő terület (ZELKO 1996: 97). Mindez egyébként egybeesett a magyar gyepünek a Kerka-Mura-Dráva folyók vízgyüjtő területére való kiterjesztésével (ZELKO 1972: 5). A Muravidék mind államigazgatási, mind pedig egyházszervezeti szempontból megosztott volt: északi része Vas vármegyéhez és a Győri püspökséghez tartozott, míg déli része Zala vármegyéhez tartozott és a Zágrábi püspökség fennhatósága alatt állt. Egyházi szempontból változást jelentett a Szombathelyi püspökség 1777-es megalapítása, amelynek köszönhetően a Muravidék északi és déli része hosszú évszázadok után végre egyesülhetett. A trianoni békeszerződés értelmében a Muravidék az újonnan megalakult Szerb-HorvátSzlovén Királysághoz került. A Muravidék északi határát jelentő Rábavidék azonban a békeszerződés értelmében Magyarország része maradt, $\mathrm{s}$ ma is ide tartozik.

A magyar államigazgatási rendszerhez való tartozás mindenképpen kedvezett a magyar-szlovén nyelvi kapcsolatok elmélyülésének, ám nem hagyhatjuk figyelmen kívül azokat az egyéb nyelven kívüli tényezőket sem, amelyek szintén hatással voltak a magyar nyelvi hatás érvényesülésére. Az egyik ilyen tényező az volt, hogy a muravidéki szlovén fiatalok tanulmányaikat magyar városokban (Kőszeg, Sopron, Szombathely) is folytatták, ahol nem csak a magyar nyelvet sajátíthatták el, hanem a magyar kultúrával is alaposan megismerkedhettek. Nem hagyhatjuk figyelmen kívül a magyar nyelv presztízsét sem, amely a soknemzetiségü történelmi Magyarországon a legtöbb beszélővel bírt, s 1844-től államnyelvnek is számított. Végül meg kell említenünk a Muravidéken élő autochton magyar kisebbséget is, amely évszázadok óta garantálja és őrzi a magyar nyelv muravidéki jelenlétét. A magyar nyelv tehát a magyarok és szlovénok által vegyesen lakott területeken jelen volt és van a mai napig, amely természetesen a két nyelvre is hatással van; igaz, az utóbbi időben a szlovén dominanciája figyelhető meg. (A muravidéki magyar nyelv jelenlegi helyzetéről részletesebben 1. BOKOR 2009.)

2. Magyar jövevényszavak a muravidéki szlovén irodalmi nyelvben. A muravidéki szlovén irodalmi nyelvben, amelynek irodalmi nyelvi normája a 18. sz. második felében alakult ki, számos magyar jövevényszó honosodott meg. Mielött

Magyar Nyelv 112. 2016: 444-450. DOI: 10.18349/MagyarNyelv.2016.4.444 
azonban a magyar jövevényszavak részletesebb elemzésébe kezdenénk, szólnunk kell a szókölcsönzés néhány általános kérdéséről is.

A jövevényszavak átvételét mindig valamilyen szükséglet hozza létre, például új eszközök, fogalmak megismerése, amelyek az átvevő nyelv kifejezéskészletéből hiányoznak, így az üres helyeket az átadó nyelv megfelelő szavai töltik ki (NYOMÁRKAY 2007: 106). Olykor az is elöfordulhat, hogy ugyan az átvevő nyelv rendszerében van megfelelő szó az adott eszköz, fogalom kifejezésére, mégis jövevényszó átvételére kerül sor. Ennek egyik tipikus példája a magyar nyelvben a szláv eredetü kovács főnév, amelyre a régi magyarban a verő főnevet használták, mégis a szláv eredetü kovács teljesen kiszorította a verő szót. A szakirodalom az ilyen jövevényszavakat „luxus jövevényszavak”-nak nevezi, amelyek általában igen intenzív és sok területre kiterjedő idegen nyelvi hatás eredményeképp jelennek meg az átvevő nyelv rendszerében (NYOMÁRKAY 2007: 106). A jövevényszó az átvevő nyelv rendszerébe kerülve beilleszkedik annak fonológiai, morfológiai és szintaktikai rendszerébe. Ez elsősorban a tipológiailag különböző nyelvek esetében kifejezetten érdekes, ilyen a muravidéki szlovén (flektáló nyelv) és a magyar (agglutináló nyelv) példája. A magyar eredetü jövevényszavak közül tehát a föneveknek ugyanúgy valamelyik nyelvtani nem kategóriájába kell tartozniuk, mint a muravidéki szlovén eredetüeknek. Emellett a magyar jövevényszavak a szóképzésben is aktívan kivették részüket, tehát bizton állíthatjuk, hogy megszüntek az átvevő nyelv rendszerében idegen elemnek lenni (HADROVICS 1989: 31).

2.1. A magyar jövevényszavak rétegződése a muravidéki szlovén irodalmi nyelvben. A muravidéki szlovén irodalmi nyelv jövevényszavainak kutatása jelen esetben csupán a köznevekre korlátozódott, a tulajdonneveket nem érintette. A magyar jövevényszavak korpusza ötven forrásmü kicédulázásával alakult ki. A forrásul szolgáló könyvek kiválasztásakor célom az volt, hogy a muravidéki szlovén irodalom kezdeteitől (18. sz. első fele) egészen az első világháború kitöréséig megjelent könyvek legyenek képviselve. Igyekeztem törekedni a müfaji változatosságra is, ám mivel a legtöbb muravidéki szlovén nyelvü könyv vallásos tematikájú, így értelemszerúen az ilyen szövegek száma nagyobb. Emellett a forrásmüvek között találhatók ábécés- és olvasókönyvek, tankönyvek, egy a Magyar Királyság történetét bemutató mủ, népmüvelö könyv, illetve az első muravidéki szlovén nyelvủ újság első teljes évfolyama. Érdekességképp Kardos János Toldi estéje fordítását is feldolgoztam.

Ennek a korpusznak az alapján alakult ki gyüjtésem, amelyben a magyar jövevényszavak száma alakváltozatokkal és származékszavakkal együtt meghaladja a hatszázat. Szófaji megoszlás tekintetében a legtöbb jövevényszó fönév; pl. bunda 'bunda', eršek 'érsek', kanas 'kanász', pelda 'példa', šišak 'sisak'. A főnév mellett az ige is gyakori szófajnak számít, pl. bantüvati 'bánt, szomorít', čujskati se 'csúszkál', engedüvati 'enged, engedelmeskedik', kodivati/koudivati 'koldul', vesnoti 'elveszik'. Az igénél is kevesebb a melléknevek száma, pl. barnasti/brnasti 'barna', čalaren 'csaló', hamičen/hamišen 'hamis', lendjelski 'lengyel', tolvajski 'tolvaj'. Az egyéb szófajok igen ritkának számítanak, pl. jezero 'ezer', ejnje 'ejnye'. 
A magyar jövevényszavakat különböző fogalomkörök szerinti csoportokba sorolhatjuk: 1. Anyagi és tárgyi kultúra (69 szó); pl. bot 'bot', kantar 'kantár', šuba 'suba'. 2. Fogalmak (59 szó); pl. bin 'bün', djülejšs 'gyülés', saga 'szag'. 3. Egyház, vallási élet (41 szó); pl. alduvati/aldüvati 'áldoz', jeretnik 'eretnek', žoltar 'zsoltár'. 4. Foglalkozások (24 szó); pl. bereš 'béres', inaš 'inas', sakač 'szakács'. 5. Tevékenységek (20 szó); pl. kivanüvati 'kíván', rendeluvati/rendelüvati 'rendelkezik, rendel', turbekati 'turbékol'. 6. Hadi és katonai terminológia (16 szó); pl. čata 'csata', šereg 'sereg', šišak 'sisak'. 7. Állatok (15 szó); pl. birka 'birka', somar 'szamár', šaška 'sáska'. 8. Helyet jelölő szavak (14 szó); pl. bauta 'bolt', lugaš 'lugas', salaš 'szállás'. 9. Tulajdonságok (11 szó); pl. butasti 'buta', hitvani 'hitvány', šantavi 'sánta'. 10. Államigazgatás és igazságszolgáltatás (10 szó); pl. követ 'követ', orsag 'ország', vama 'vám'. 11. Növények (10 szó); pl. egriš 'egres', kolomper 'burgonya', kukorica 'kukorica'. 12. Mennyiséget jelölő szavak (6 szó); pl. akouv 'akó', falat 'darab', talejr/tallejr 'tallér'. 13. Ételek, italok (4 szó); pl. reteš 'rétes', šör 'sör', tej 'tea'. 14. Nemzetiség (4 szó); pl. Horvat 'horvát', lendjelski 'lengyel', totski 'szlovák, tót'. 15. Indulatszó (3 szó): ejnje 'ejnye', nossa 'nosza', uсcu 'uccu'. 16. Testrészek (2 szó): bajusi 'bajusz', čonta 'csont'. 17. Szám: jezero 'ezer'. 18. Család: apa 'apa'.

Amint az a fentebbi adatokból is jól látható, a legtöbb magyar jövevényszó az anyagi és tárgyi kultúra, valamint a fogalmak körében honosodott meg. Nagynak mondható az egyházi, vallási életben meglévő magyar elemek száma is. Némiképp meglepő módon az államigazgatási és igazságszolgáltatási terminológiában kevés a magyar eredetű szó, holott talán a közös államigazgatási rendszerhez való tartozás alapján feltételezhetnénk, hogy számottevőbb magyar hatásnak volt kitéve ez a terminológia is.

2.2. A magyar jövevényszavak beilleszkedése a muravidéki szlovén irodalmi nyelv rendszerébe. Az elmúlt évtizedek során a nyelvi kapcsolatok elméletének igen kiterjedt szakirodalma alakult ki, ám a jövevényszavak beilleszkedésével kapcsolatban a leginkább áttekinthető rendszert a horvát RUDOLF FILIPOVIĆ (1986) alkotta meg. A jövevényszavak beilleszkedése során helyettesítésről (szubsztitúcióról) a fonémák és morfémák szintjén beszélhetünk, amelyet transzfonemizáció-nak és transzmorfemizáció-nak nevezünk (FILIPOVIĆ 1986: 68). Transzfonemizáció-nak az átvevő nyelv fonémáinak az átvevő nyelv fonémáival való helyettesítését hívjuk (FILIPOVIĆ 1986: 69). Az átvevő nyelv fonémarendszerének üres helyei sohasem fonémaátvétellel töltődnek ki, hanem a fonémarendszeren belül lezajló változás hatására fellépő specifikus feltételek és meghatározott kényszer hatására megy végbe (FILIPOVIĆ 1986: 79). Új fonéma a nyelven belül már létező allofónból jöhet létre (FILIPOVIĆ 1986: 81). A transzmorfemizáció-nak nevezett jelenség jelen esetben legfontosabb esete az, amikor az átadó nyelv kötött morfémája, amely nincsen meg az átvevő nyelv rendszerében, helyettesítődik egy, az átvevő nyelv rendszerébe illeszkedő kötött morfémával (FILIPOVIĆ 1986: 123). Itt jegyezzük meg, hogy ez az a morféma, amelyet HADROVICs LÁszLó (1975: 12) honosító képzö-nek nevez.

2.2.1. Fonémahelyettesítés. Fonémahelyettesítésre abban az esetben kerül sor, ha az átvevő nyelv fonémarendszeréből hiányzik az adott fonéma, vagy ugyan része annak, ám a jövevényszóban lévő pozícióban nem fordul elő (BÁRCZI 1958: 46). 
2.2.1.1. A magánhangzók. A muravidéki szlovén és a magyar magánhangzók között sok az egyezés, így fonémahelyettesítésre csupán az /e:/, /o:/ és az /p/ esetében került sor. Nem okoz nehézséget az /ø/ és /y/ fonéma átvétele, ugyanis ezek a muravidéki szlovénban is megvoltak (vö. PÁVEL 1909: 64-71); pl. djöndj 'gyöngy', követ 'követ', šör 'sör', džündž 'gyöngy', djülejšs 'gyülés', püšpek 'püspök'. Egy esetben viszont $/ \varnothing / \rightarrow / 0$ / fonémahelyettesítést figyelhetünk meg a szó belsejében: magy. örök $\rightarrow$ mszln. örok 'örökség'. Fonémahelyettesítésre került sor a magyar /ø:/ esetében is, amelyet a szó végén /e/ fonémával helyettesítettek: magy. cipellö $\rightarrow$ mszln. cipele 'cipö'.

A magy. /e:/ - ritkábban /e/ - fonémát a muravidéki szlovénban /ej/ diftongussal helyettesítették: cejh 'céh', cimejr 'címer', djülejšs 'gyülés', filejr 'fillér', kanapej 'kanapé', kejp 'kép', kertejs 'kertész', profejta 'próféta', talejr/tallejr 'tallér', tanjejr 'tányér'. Hozzátehetjük, hogy némely fönévnek van alakváltozata is: cimer, filer/filler, kep, kertes, profeta. Ennek okára pontos választ nem adhatunk, ám figyelemreméltó, hogy az e-s alakváltozatok inkább a 19. sz. második és a 20. sz. első felének íróinál fordulnak elő.

A magy. /o:/ - ritkábban /o/ - fonémát szó belsejében a muravidéki szlovénban /ou/ diftongussal helyettesítették: korouna 'korona', kouruš 'kórus', mouduoš 'érték, birtok', šinagouga 'zsinagóga', trounuš 'trón'. Ebben az esetben is elöfordulnak alakváltozatok, amelyekben a diftongus helyén monoftongust találunk: korona, koruš, tronuš. Szó végén az /o:/ fonémát /ov/-val helyettesítik, amely / ouv/-vá diftongizálódhat: birov 'bíró', föbirov 'föbíró', hajov 'hajó', akouv 'akó', birouv 'bíró', hajouv 'hajó', hintouv 'hintó'. Egyetlen példában a magy. /o:/ helyén /o/, illetve /ou/ áll: sabo/sabou 'szabó'.

A magyar / $\mathrm{p} /$ fonémát egy esetben /o/ fonémával helyettesítették: somar 'szamár'. Ehhez a fonémához hasonló hangot ejtenek a muravidéki szlovén két dialektusában, a dombvidékiben (goričko-i) és síkvidékiben (ravensko-i) (RAMOVŠ 1935: 186). PÁvEL ÁGOSTON (1909: 8) véleménye szerint a cankovai dialektus magyar jövevényszavai esetében a magy. / $/$ / megmarad; pl. baga 'bagó', falat 'falat', saga 'szag'.

2.2.1.2. A mássalhangzók. A mássalhangzók közül csupán a magy. /n/ és /c/ fonéma esetében került sor fonémahelyettesítésre, amelyet a magyar és muravidéki szlovén mássalhangzórendszer hasonlóságával magyarázhatunk. A magy. $/ \mathrm{n} /$ a jövevényszavak belsejében változás nélkül megmaradt, azonban a szó végén depalatalizálódik, magy. /n/ $\rightarrow$ mszln. /n/; pl. baršon 'bársony', dohan 'dohány', hitvan 'hitvány', šarkan 'sárkány'. Meg kell azonban jegyeznünk azt is, hogy ezeknek a szavaknak a magyarban is előfordult depalatalizált alakváltozatuk, ugyanis a magyarban az $/ \mathrm{n} />/ \mathrm{n} /$ palatalizáció az ómagyar korban kezdődött (E. ABAFFY 2005: 307). Továbbá azt is hozzátehetjük, hogy a depalatalizált alakváltozatok megjelenését és elterjedését a muravidéki szlovénban az is elősegíthette, hogy nem csak a jövevényszavak esetében érvényesült a szóvégi $/ \mathrm{n} />/ \mathrm{n} /$ depalatalizáció (PÁVEL 1909: 115; RAMOVŠ 1935: 188). Ebben az esetben tehát nem tudjuk teljes bizonyossággal eldönteni, hogy a magy. /n/ fonéma /n/ fonémával való helyettesítésével van-e dolgunk, vagy pedig belső muravidéki szlovén fejlődés eredménye a depalatalizált alak. 
A muravidéki szlovén nyelvterület északi részén, a dombvidéki (goričko-i) dialektusban van /c/ fonéma, de nem hiányzik PÁVEL ÁGOSTON szülőfalujának, a dombvidéki és síkvidéki dialektus határán elhelyezkedő Cankova nyelvjárásából sem (vö. PÁVEL 1909: 124-126). Mivel azonban a muravidéki írók többsége vagy a síkvidéki, vagy pedig a völgyvidéki dialektust beszélte anyanyelveként, s nem a dombvidékit, így a magyar jövevényszavak esetében a /c/ fonémát /t/ vagy / t $/$ / fonémával helyettesítik; pl. bašta 'bástya', fačuk 'fattyú'. A fačuk esetében a /tg/vel való helyettesítés a /c/ fonéma intervokális helyzetével magyarázható.

2.2.1.3. Az idegen eredetű szavak magyar fonémahelyettesítésének megőrzése. A muravidéki szlovén irodalmi nyelv magyar jövevényszavai között számos olyat találunk, amely a magyarban is idegen eredetü (latin, német, olasz, szláv, török). Ezek a jövevényszavak a magyarban bekövetkezett változást követően kerültek a muravidéki szlovénba, így azokat magyar jövevényszavaknak kell tekintenünk, hiszen megörzik a magyarban bekövetkezett változásokat.

A latin /s/ fonémából a magyarban / $/$, intervokális helyzetben pedig / $/ 3$ fonéma alakult. Ezt a helyettesítést a muravidéki szlovén is megőrizte; pl. šinagouga 'zsinagóga', šorš 'sors', illetve hožanna 'hozsanna', mužika 'muzsika'.

A német eredetủ szavak esetében az intervokális /o/ fonémát /p/ vagy /a/ fonémával helyettesítették a magyarban, amelyet a muravidéki szlovén is megörzött; pl. bak 'bak' (< baj.-osztr. bock), parta 'párta' (< baj.-osztr. porte, kfn. borte). A német eredetü szavak szókezdő/b/ fonémáját a magyar/p/-vel helyettesíti, amelyet szintén megőrzött a muravidéki szlovén; pl. pantlik/pantlika/plantlik 'pántlika' ( $<$ baj.-osztr. bandl, bantl), porkolab 'porkoláb' ( $<$ kfn. purcrāv [e], burcgrâve).

Számos olyan magyar jövevényszó került a muravidéki szlovénba, amely a magyarban szláv eredetủ, azonban a magyarban bekövetkezett változások megtartásával kerültek át a muravidéki szlovén irodalmi nyelvbe. Az alábbi tendenciákat figyelhetjük meg: $1 . / \mathrm{o} / \rightarrow / \mathrm{p} /$ fonémahelyettesítés a szó elején vagy a szó belsejében; pl. magy. akó > mszln. akouv 'akó', magy. apát > mszln. apat 'apát', magy. apátúr > mszln. apatur 'apát', magy. baj > mszln. baja 'baj', magy. gazda $>$ mszln. gazda 'gazda', magy. vajda > mszln. vajda 'vajda'. 2. Szláv /e/ $\rightarrow$ magy. /p/; pl. magy. csata $>$ mszln. čata. 3. Szó eleji mássalhangzó-torlódás feloldása; pl. magy. barát $>$ mszln. barat 'szerzetes', magy. bereg/berek $>$ mszln. bereg/ berek 'berek', magy. horvát > mszln. Horvat 'horvát férfi'. 4. Szláv nazális /ę/ megőrzése; pl. magy. lengyel > mszln. lendjelski 'lengyel'. 5. Szó belsejében az /i/ kiesésének megtartása; pl. magy. pálca $>$ mszln. palca 'pálca'. 6. Szemantikai kölcsönzés; pl. akouv, baja, barat, bereg/berek, pandur 'pandúr'. 7. Nem déli szláv eredetü szó kölcsönzése; pl. magy. pálinka > mszln. palinka.

2.2.2. Morfémahelyettesítés. Morfémahelyettesítés esetén az átadó és az átvevő nyelv tipológiai hovatartozása döntő szereppel bír. Az agglutináló magyar nyelvből származó jövevényszavaknak be kell illeszkedniük a flektáló muravidéki szlovén nyelv deklinációs és konjugációs rendszerébe, hogy mind a névszók, mind pedig az igék ragozhatóvá váljanak. Ezt a beilleszkedést a HADROVICS LÁSZLÓ (1975: 12) által honositó képző-nek nevezett képzők segítik elő.

2.2.2.1. A főnevek honosító képzői. A magyar fönevek esetében a legfontosabb kritérium, hogy a muravidéki szlovén fönevek grammatikai nem kategó- 
riájába besorolhatók legyenek, s így a deklinációs rendszerben ragozhatóvá váljanak. Három honosító képző vált gyakorivá a főneveknél: 1. -a, pl. baja 'baj', barda 'bárd', bauta 'bolt', čonta 'csont', fela 'féle', gomba 'gomb', kefa 'kefe', kočia 'kocsi', oproda 'apród', saga 'szag', vama 'vám', varmedja/varmedjeval varmedjija/varmedjöva 'vármegye'; 2. -i, pl. bajusi 'bajusz', hami 'hám'; 3. -ek, pl. hasek 'haszon'. A leggyakoribb honosító képző a fönevek körében tehát az - $a$ volt, azaz ezek a szavak nőnemủek lettek. Az -i honosító képző hozzáadásával a magyar jövevényszó plurale tantum lett a muravidéki szlovénban.

2.2.2.2. A melléknevek honosító képzői. Igen kevés melléknevet találunk a magyar jövevényszavak között, inkább az átvett főnevekből és igékből képeztek mellékneveket. Ennek ellenére a melléknevek esetében is többféle honosító képzőt találunk: 1. -asti, pl. barnasti/brnasti 'barna', butasti 'buta'; 2. -avi, pl. djingavi/gingavi/ginglavi 'gyenge', šantavi 'sánta'; 3. -en, pl. čalaren 'csalárd', hamičen/hamišen 'hamis', hirešen 'híres'; 4. -skil-ški, pl. lendjelski 'lengyel', nemeški 'nemes'.

2.2.2.3. Az igék honosító képzői. Valamennyi, a muravidéki szlovénba átvett ige kap honosító képzőt: 1. -ati, pl. koronati 'koronáz', šantati 'sántít', šarcati se 'sarcol', turbekati 'turbékol', zbantati 'megbánt'; 2. -avati, pl. predikavati 'prédikál'; 3. -iti, pl. batoriti 'bátorít, vigasztal', dičiti 'dicsér, dicsőít', koroniti 'koronáz', tanačiti 'tanácsol', vadliti 'vall'; 4. -ivati, pl. batrivati 'bátorít, vigasztal', citaralivati 'citeráz', šilabizalivati 'silabizál', tanačivati 'tanácsol', zbantivati 'megbánt'; 5. -iviti, pl. batriviti 'bátorít, vigasztal'; 6. -ovati, pl. harcovati se 'harcol'; 7. -uvati/-üvati, pl. alduvati/aldüvati 'áldoz', bantüvati 'bánt', engedüvati 'emged', kebzüvati 'vigyáz', kivanüvati 'kíván', koronüvati 'koronáz', mentuvati/ mentüvati 'ment', predikuvati/prediküvati 'prédikál', prikačüvati 'hozzákapcsol', rendeluvati/rendelüvati 'rendel', šarcuvati se 'sarcol', tanačüvati 'tanácsol', vadluvati/vadlüvati 'vall', verostüvati/veröstüvati/verustüvati/virostüvati/ vörustuvati/vörustüvati 'virraszt', zbantuvati/zbantüvati 'megbánt'.

Amint azt a példák száma is jól mutatja, a leggyakoribb honosító képző az -uvatil-üvati volt, míg az -avati, -iviti, -ovati honosító képzők csupán egy-egy esetben fordulnak elő. A muravidéki szlovénba átvett magyar igék aspektusukat tekintve folyamatosak.

2.2.3. A protetikus $j$-. A muravidéki szlovén nyelv $j$ - és $v$ - protetikus hangot ismer, amelyek közül a j-t a következö jövevényszavak kapták meg: jal 'álnokság', jeretnik 'eretnek', jezero 'ezer'.

3. Összefoglalás. A magyar - muravidéki szlovén nyelvi kapcsolatok eredményeképp a különböző származékokkal és alakváltozatokkal együtt több mint hatszáz magyar eredetủ szó élt a muravidéki szlovén irodalmi nyelvben. A magyar jövevényszavakat különböző fogalomkörökbe sorolhatjuk. A legtöbb magyar jövevényszó az anyagi és tárgyi kultúra körébe tartozik, vagy pedig valamilyen fogalmat jelöl. A jövevényszavak között szófaji gyakoriságot tekintve a fönevek vezetnek, az igék és melléknevek száma kevesebbnek mondható a főnevekéhez képest. A magyar jövevényszavaknak a muravidéki szlovén nyelvbe kerülve be kellett illeszkedniük annak fonológiai és morfológiai rendszerébe. Láthattuk, hogy 
a fonémahelyettesítés csupán néhány fonémára korlátozódik, amelyet a magyar és muravidéki szlovén fonémarendszer nagyfokú egyezésével magyarázhatunk. A morfémahelyettesítés során honosító képzők járultak egyes főnevekhez, melléknevekhez és igékhez, ami a magyar jövevényszavaknak a muravidéki szlovén deklinációs és konjugációs rendszerbe való beilleszkedését szolgálta.

Kulcsszók: magyar nyelv, muravidéki szlovén irodalmi nyelv, jövevényszavak, fonémahelyettesítés, morfémahelyettesítés.

\section{Hivatkozott irodalom}

E. ABAFFY ERZSÉBET 2005. Hangtörténet. In: KISS JENŐ - PUSZTAI FERENC szerk., Magyar nyelvtörténet. Osiris Kiadó, Budapest. 301-351.

BÁRCZI GÉZA 1958. A magyar szókincs eredete. Tankönyvkiadó, Budapest.

BOKOR JÓZSEF 2009. Nyelviség és magyarság a Muravidéken. Magyar Nemzetiségi és Müvelődési Intézet, Lendva.

FiLIPOVIĆ, RUDOLF 1986. Teorija jezika u kontaktu. Uvod u lingvistiku jezičnih dodira. JAZU - Školska knjiga, Zagreb.

HADROVICs LÁszLó 1975. Szavak és szólások. Nyelvtudományi Értekezések 88. Akadémiai Kiadó, Budapest.

HADROVICS LÁSZLÓ 1989. A magyar nyelv kelet-közép európai rokonsága. In: BALÁzS JÁNOS szerk., Nyelvünk a Duna-tájon. Tankönyvkiadó, Budapest. 7-46.

NYOMÁRKAY ISTVÁN 2007. Rövid horvát és szerb nyelvtörténet. ELTE BTK Szláv Filológiai Tanszék, Budapest.

PÁvel ÁGost 1909. A vashidegkuti szlovén nyelvjárás hangtana. Magyarországi Szláv Nyelvjárások 1. Akadémiai Kiadó, Budapest.

RAMOVŠ, FRAN 1935. Historična gramatika slovenskega jezika. VII. Dialekti. Učiteljska tiskarna, Ljubljana.

ZelKo, Ivan 1996. Zgodovina Prekmurja. Pomurska založba, Murska Sobota.

\section{Hungarian loanwords in the system of the Mur Region Slovene literary language}

The paper discusses the phonological and morphological integration of Hungarian loanwords in the Prekmurje (Mur Region) Slovene literary language. After a brief introduction to the history of Hungarian-Slovene linguistic contacts in the Mur Region, the discussion covers the layering of Hungarian loanwords in the Mur Region Slovene literary language. Phoneme substitution is demonstrated phoneme by phoneme, whereas morpheme substitution is shown separately for each part-of-speech category.

Keywords: Hungarian language, Prekmurje Slovene literary language, loanwords, phoneme substitution, morpheme substitution. 